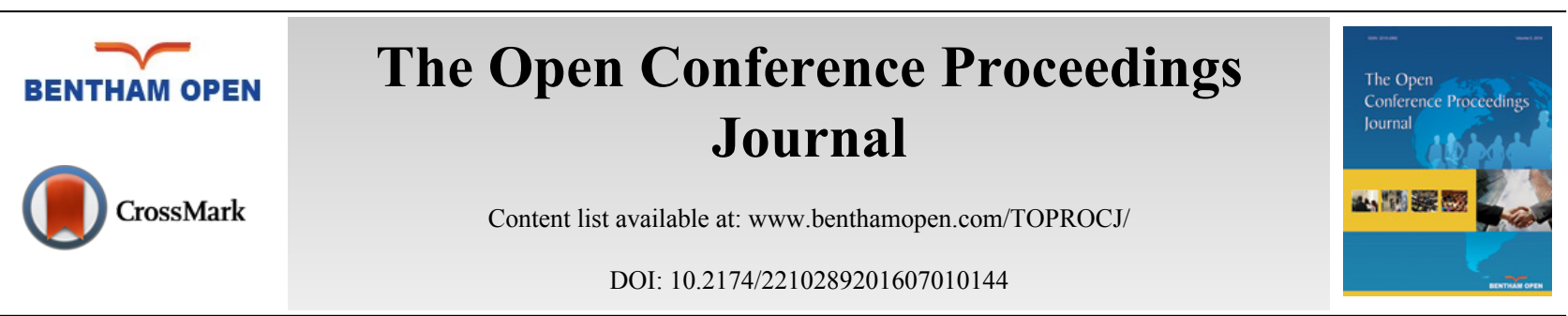

RESEARCH ARTICLE

\title{
Evaluation of High Beta Carotene Cassava Genotypes at Advanced Trial in Nigeria
}

\author{
N.L. Edoh", J. Adiele, I. Ndukwe, H. Ogbokiri, D.N. Njoku and C.N. Egesi \\ Biotechnology Programme, National Root Crops Research Institute, P.M.B. 7006 Umudike, Umuahia Abia State, \\ Nigeria
}

\begin{abstract}
Thirteen cassava genotypes were evaluated from advanced field trial for total carotene content (TCC), \% dry matter content (DMC), fresh root yield (FRY) and biotic stresses alongside two widely cultivated cassava varieties (UMUCASS 36 and TMS 30572) as checks in 2013/2014 cropping season at research station of National Root Crops Research Institute (NRCRI) Umudike in Nigeria. The objective of the experiment was to select promising clones for possible release to Nigeria farmers. The results of the TCC analysis ranged from 1.68-10.16 $\mu \mathrm{g} / \mathrm{g}$. Genotypes NR11/0063, NR11/0123 and NR11/0140 had TCC ranged from 10.47-8.72 $(\mu \mathrm{g} / \mathrm{g})$ which are above the national checks (UMUCASS 36 and TMS 30572) of 8.34 and 1.68( $\mu \mathrm{g} / \mathrm{g})$ respectively. The DMC of the genotypes ranged from 33.0-15.0 \%. TMS 30572 gave the highest DMC (33.0\%) while genotype NR11/0064 had the least (15.0\%) DMC. Severity of cassava mosaic disease (CMD), cassava bacterial blight (CBB), cassava green mite (CGM) and cassava anthracnose disease (CAD) evaluated for 12 months varied among the genotypes. Symptom expressions of CMD, CBB and CAD were relatively higher (3.0) for genotype NR11/0123 and this resulted to low fresh root yield (FRY) of 18 t/ha whereas TMS 30572 with moderate severity (1.8) had a higher FRY of $32.6 \mathrm{t} / \mathrm{ha}$. The severity of CGM was moderate across the genotypes with no significant difference $(\mathrm{P}<0.05)$ observed. Further analysis showed that $\mathrm{CMD}$, CBB and CAD were significantly correlated $(\mathrm{r}=0.618$, 0.699 and $0.621, \mathrm{p}<0.05)$ with harvest index $(\mathrm{HI})$ among the genotypes evaluated. Three genotypes were selected for further evaluation and possible release to Nigeria farmers.
\end{abstract}

Keywords: Biotic stress, Cassava, High Beta-carotene, Harvest index.

\section{INTRODUCTION}

Vitamin A deficiency (VAD) is a global public health problem that impacts millions around the world [1]. Vitamin A deficiency is a leading cause of morbidity and mortality, especially in young children, pregnant and lactating women. Food-based interventions focused on alleviating vitamin A deficiency in susceptible populations have advantages over supplementation and fortification programmes, especially in rural areas, because they can provide a sustainable source of variety of nutrients without the recurring transport and administration costs of these other methods [2]. Three main strategies have been traditionally used to prevent vitamin A deficiency: dietary diversification, food fortification and supplementation. These strategies are relatively cost-effective, but have failed to completely eradicate the problem for a diversity of reasons [3]. Among these initiatives is the development of biofortified cassava varieties with high provitamin A carotenoid contents in the roots. Biofortification can be achieved through conventional breeding techniques that take advantage of the genetic variability for micronutrients in different crops [4 - 7]. It represents a sustainable strategy that aims at solving the protracted micronutrient problem.

Cassava is a starchy root crop, with many positive attributes. It is drought resistant, inexpensive, resistant to pests and easy to grow. Although it is a valuable source of energy, typically it is a poor source of pro-vitamin A carotenoids $[8,9]$. Among the starchy staples, cassava gives a carbohydrate production which is about $40 \%$ higher than rice and $25 \%$ more than maize. Furthermore, cassava is the cheapest source of calories for both human nutrition and animal feed

* Address correspondence to this author at the Biotechnology Programme, National Root Crops Research Institute, P.M.B. 7006 Umudike, Umuahia Abia State, Nigeria; Tel: +2348035662511; E-mail: edohlink@yahoo.com,nedoh@danforthcenter.org 
[10]. Cassava is among the most popular staple foods in Nigeria, therefore a valid strategy to reduce vitamin A deficiency among the people is to enhance its nutritional value through plant breeding and genetic transformation (transgenic). Although cassava leaves are sometimes consumed, the major harvested organ is the storage root. The plant is propagated mostly from stem cuttings. More than two-thirds of the total production of cassava is used as food for humans, with lesser amount being used for animal feed [11] and industrial purposes. The primary goal of this trial is to identify genotypes of high beta-carotene content of adaptive capacity with resistance to major diseases and pests for possible release to Nigeria farmers and clones for the introgression of other desirable traits through genetic modification.

\section{MATERIALS AND METHODS}

The experiment was established in the Western farm of NRCRI Umudike on the September 20, 2013. Thirteen high beta carotene cassava genotypes were selected from preliminary yield trial to be evaluated alongside 2 checks (TMS 30572 and UMUCASS 36). UMUCASS 36 (TMS 01/1368) was a conventionally bred pro-vitamin A cassava variety released to Nigerian farmers in 2012 while TMS 30572 is the farmers preferred variety. The thirteen genotypes were planted for one cropping season. The land was ploughed, harrowed and ridged. The field layout was randomized complete block design replicated three times. Thirty six stem cuttings of each genotype were planted in a $6 \mathrm{~m} \mathrm{x} 6 \mathrm{~m}$ plot at a spacing of $1 \mathrm{~m}$ along ridges made $1 \mathrm{~m}$ apart. NPK 20-10-10 fertilizer was applied 6weeks after planting and weeds were controlled manually as at when due. The genotypes were scored for growth parameters and response to major pests and diseases (cassava mosaic disease, cassava bacterial blight and cassava anthracnose disease and cassava green mite) of cassava at 1, 3, 6, and 9 months after planting (MAP) on a 5-point scale ( 1 no symptom and 5 being severe). Shortly before harvest (12 MAP), the genotypes were evaluated for percentage dry matter and total carotene content using the methods described by Asare [12]; Rodriguez-Amaya and Kimura [13] respectively. At 12 months the harvest parameters were taken and data collected included root weight per plot, specific gravity of the roots, fresh shoot weight and number of roots per plot. The statistical analysis was carried out using Analytical of Variance (ANOVA) and Pearson correlation analysis.

\section{RESULTS AND DISCUSSION}

Thirteen genotypes were subjected to total carotene content (TCC) analysis. The result of TCC recorded among the yellow roots ranged from $2.29-10.47 \mu \mathrm{g} / \mathrm{g}$. Genotype NR11/0123 had the highest carotene content $10.47 \mu \mathrm{g} / \mathrm{g}$ while NR11/0124 had the least $2.29 \mu \mathrm{g} / \mathrm{g}$. The carotene content of the positive and negative checks UMUCASS 36 (TMS 01/1368) and TMS 30572 were 8.34 and $1.68 \mu \mathrm{g} / \mathrm{g}$ respectively (Table 1). Genotypes NR11/0123, NR11/0063 and NR11/0140 had their TCC above the national check UMUCASS 36 (Fig. 1). These genotypes could provide more vitamin A in diets and contribute to reducing vitamin A deficiency which is widespread in Nigeria. Following the agricultural transformation agenda, there is a great need to scale up micronutrients in staple foods produced in the country [14]. Carotenoids from vegetables contribute two-thirds of dietary Vitamin A, worldwide, and more than $80 \%$ in the developing world [15]. Carotenoid content (expressed on a fresh weight basis) increases with the age of the plant. But this expectation was drastically affected by the unusual variation in DMC [16]. The percentage dry matter content (DMC) of the 13 genotypes ranged from 15-33.5\% with NR11/0124 as the highest (33.5\%). Severity of cassava mosaic disease (CMD), cassava bacterial blight (CBB), cassava green mite (CGM) and cassava anthracnose disease (CAD) varied among genotypes and the cropping year. Symptom expressions of CMD, CBB and CAD were relatively higher (3.0) for genotype NR11/0123 and this resulted to low fresh root yield (FRY) of $18 \mathrm{t} / \mathrm{ha}$ whereas TMS 30572 with moderate severity (1.8) had a higher FRY of $32.6 \mathrm{t} / \mathrm{ha}$. The severity of CGM was moderate across the genotypes. The traits measured were further examined using correlation analysis (Table 2). A positive correlation coefficient $(\mathrm{r}=0.103$, $\mathrm{p}<0.01$ ) exists between starch content (SC) and DMC (Table 2). The CMD, CBB and CAD were significantly correlated $(\mathrm{r}=0.618,0.699$ and $0.621, \mathrm{p}<0.05)$ with harvest index $(\mathrm{HI})$ among the genotypes evaluated (Table 2) indicating the effect of biotic stress on HI. According to Baiyeri et al. [17], CMD, CBB and CAD are considered as the most important cassava diseases in Africa capable of causing an estimated $50 \%$ root yield reduction. Thus selection of genotypes possessing durable genes for resistance to these diseases portends sustainable way of enhancing cassava productivity. Fig. (1) showed the agronomic and quality traits of 6 best genotypes with the 2 checks. The lowest mean CMD score 1.89 was recorded for NR11/0140 with NR11/0123 as the highest (3.33). The lowest mean CBB score 1.44 was recorded for NR11/0124 while NR11/0123 also had the highest (3.00). In Table 1, genotype NR11/0124 scored lowest in the mean CAD recorded while genotypes NR11/0123, NR11/128 and TMS 30570 recorded the highest (3). However, severities of CGM across the genotypes were relatively low [18, 19]. It is a fundamental knowledge in crop 
science that crop growth has positive and significant relationship with yield [20,21] however; trend in disease severity and tuber yield differed. All the genotypes recorded high yield per hectare. Six out of the 13 genotypes presented good yield and traits during the 12 months cropping season, making their performance reliable. Based on the overall mean rank-sum, the most adaptable genotypes selected from this experiment were NR11/0063, NR11/0123, and NR11/0140. This is a good platform for the introgression of other desirable traits through genetic modification. Already in NRCRI production of target materials for DNA transfer is ongoing.

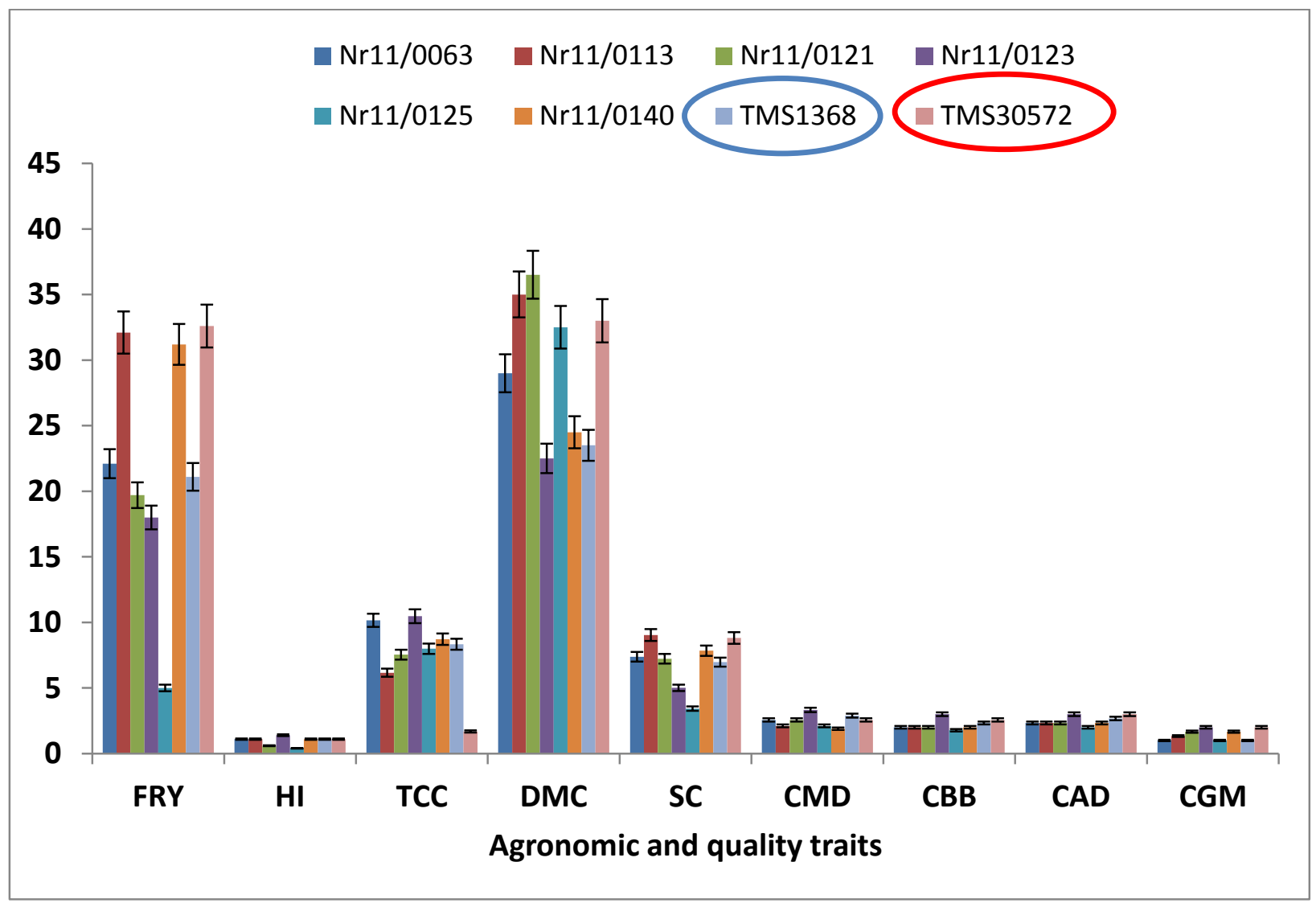

Fig. (1). Diagram showing the agronomic and quality traits of 6 best genotypes out of the 13 used in this experiment with 2 checks. CMD (Cassava mosaic disease 1-5); CBB (Cassava bacteria blight 1-5); CAD (Cassava anthracnose disease 1-5); CGM (Cassava green mite 1-5) \%); SC (Starch content \%); HI (Harvest index 0-1); DMC (Dry matter content \%), TCC (Total Carotene Content $\mu \mathrm{g} / \mathrm{g}$ ), FRY (Fresh root yield ton $\mathrm{ha}^{-1}$ ).

Table 1. Agronomic and quality traits of 13 yellow root cassava genotypes and 2 checks evaluated at Umudike.

\begin{tabular}{|l|c|c|c|c|c|c|c|c|c|}
\hline GENOTYPE & FRY & HI & TCC & DMC & SC & CMD & CBB & CAD & CGM \\
\hline Nr11/0063 & $\mathbf{2 2 . 3}$ & $\mathbf{1 . 1}$ & $\mathbf{1 0 . 1 6}$ & $\mathbf{2 9 . 0}$ & $\mathbf{7 . 3 8}$ & $\mathbf{2 . 5 6}$ & $\mathbf{2 . 0 0}$ & $\mathbf{2 . 3 3}$ & $\mathbf{1 . 0 0}$ \\
\hline Nr11/0064 & 19.6 & 0.9 & 4.87 & 15.0 & 6.82 & 2.56 & 1.89 & 2.33 & 2.00 \\
\hline Nr11/0113 & 32.1 & 1.1 & 6.16 & 35.0 & 9.04 & 2.11 & 2.00 & 2.33 & 1.33 \\
\hline Nr11/0121 & 19.7 & 0.6 & 7.54 & 36.5 & 7.23 & 2.56 & 2.00 & 2.33 & 1.67 \\
\hline Nr11/0123 & $\mathbf{1 8}$ & $\mathbf{1 . 4}$ & $\mathbf{1 0 . 4 7}$ & $\mathbf{2 2 . 5}$ & $\mathbf{5 . 0 1}$ & $\mathbf{3 . 3 3}$ & $\mathbf{3 . 0 0}$ & $\mathbf{3 . 0 0}$ & $\mathbf{2 . 0 0}$ \\
\hline Nr11/0124 & 16.1 & 0.5 & 2.29 & 33.5 & 7.39 & 1.78 & 1.44 & 1.67 & 1.00 \\
\hline Nr11/0125 & 5 & 0.4 & 7.99 & 32.5 & 3.43 & 2.11 & 1.78 & 2.00 & 1.00 \\
\hline Nr11/0128 & 27 & 1.2 & 4.57 & 20.5 & 7.56 & 2.78 & 2.56 & 3.00 & 1.67 \\
\hline Nr11/0132 & 23.6 & 1.3 & 3.19 & 30.0 & 5.60 & 2.56 & 2.00 & 2.00 & 1.00 \\
\hline Nr11/0137 & 25.9 & 1.2 & 6.36 & 24.5 & 7.42 & 2.67 & 2.22 & 2.67 & 1.00 \\
\hline Nr11/0138 & 18.9 & 0.9 & 5.31 & 26.5 & 7.34 & 2.44 & 2.33 & 2.67 & 2.00 \\
\hline Nr11/0140 & $\mathbf{3 1 . 2}$ & $\mathbf{1 . 1}$ & $\mathbf{8 . 7 2}$ & $\mathbf{2 4 . 5}$ & $\mathbf{7 . 8 4}$ & $\mathbf{1 . 8 9}$ & $\mathbf{2 . 0 0}$ & $\mathbf{2 . 3 3}$ & $\mathbf{1 . 6 7}$ \\
\hline Nr11/0186 & 25.7 & 0.8 & 2.58 & 29.5 & 6.46 & 2.11 & 2.00 & 2.33 & 1.00 \\
\hline TMS01/1368 & $\mathbf{2 1 . 1}$ & $\mathbf{1 . 1}$ & $\mathbf{8 . 3 4}$ & $\mathbf{2 3 . 5}$ & $\mathbf{6 . 9 7}$ & $\mathbf{2 . 8 9}$ & $\mathbf{2 . 3 3}$ & $\mathbf{2 . 6 7}$ & $\mathbf{1 . 0 0}$ \\
\hline
\end{tabular}


(Table $\square$ ) contd.....

\begin{tabular}{|c|c|c|c|c|c|c|c|c|c|}
\hline GENOTYPE & FRY & HI & TCC & DMC & SC & CMD & CBB & CAD & CGM \\
\hline TMS30572 & 32.6 & 1.1 & 1.68 & 33.0 & 8.81 & 2.56 & 2.56 & 3.00 & 2.00 \\
\hline Mean & 21.93 & 0.96 & 6.17 & 27.65 & 6.81 & 2.42 & 2.09 & 2.38 & 1.36 \\
\hline STD & 7.09 & 0.31 & 2.71 & 6.19 & 1.43 & 0.42 & 0.38 & 0.38 & 0.50 \\
\hline MIN & 5.00 & 0.40 & 2.29 & 15.0 & 3.43 & 1.78 & 1.44 & 1.67 & 0.67 \\
\hline MAX & 32.1 & 1.40 & 10.47 & 36.5 & 9.04 & 3.33 & 3.00 & 3.00 & 2.00 \\
\hline CV\% & 40.4 & 9.50 & 41.2 & 14.1 & 63.9 & 16.1 & 24.7 & 32.5 & 30.8 \\
\hline
\end{tabular}

FRY (Fresh root yield ton ha ${ }^{-1}$ ); HI (Harvest index 0-1); TCC (Total carotene content $\left.\mu \mathrm{g} / \mathrm{g}\right)$ ); DMC (Dry matter content \%); SC (Starch content \%); CMD (Cassava mosaic disease 1-5); CBB (Cassava bacteria blight 1-5); CAD (Cassava anthracnose disease 1-5); CGM (Cassava green mite 1-5).

Table 2. Correlation coefficients among traits of 13 yellow root cassava.

\begin{tabular}{|l|l|l|l|l|l|l|l|l|}
\hline & FRY & HI & TCC & DMC & SC & CMD & CBB \\
\hline FRY & 1 & 0.603 & $\mathbf{- 0 . 2 5 3}$ & -0.025 & $0.803^{* *}$ & -0.018 & 0.276 \\
\hline HI & & 1 & 0.185 & -0.449 & 0.244 & $\mathbf{0 . 6 1 8 *}$ & $\mathbf{0 . 6 9 9 *}$ \\
\hline TCC & & & 1 & -0.188 & $\mathbf{- 0 . 2 7 9}$ & 0.354 & 0.242 \\
\hline DMC & & & & 1 & $\mathbf{0 . 1 0 3}$ & -0.463 & -0.372 \\
\hline SC & & & & & 1 & -0.177 & 0.029 \\
\hline CMD & & & & & 1 & -0.422 & $0.815^{*}$ \\
\hline CBB & & & & & & & 0.253 & 1 \\
\hline CAD & & & & & & & & $0.933^{* *}$ \\
\hline
\end{tabular}

* Correlation is significant at the 0.05 level (2-tailed).

** Correlation is significant at the 0.01 level (2-tailed).

CMD (Cassava mosaic disease 1-5); CBB (Cassava bacteria blight 1-5); CAD (Cassava anthracnose disease 1-5); CGM (Cassava green mite 1-5) \%); SC (Starch content \%); HI (Harvest index 0-1); DMC (Dry matter content \%), TCC(Total Carotene Content $\mu \mathrm{g} / \mathrm{g}$ ).

\section{CONCLUSION}

Results showed that all the 13 genotypes investigated had their total carotene content (TCC) above the farmers' preferred variety (TMS 30572, negative check) while genotypes Nr11/0063, Nr11/0123 and Nr11/0140 had their TCC above UMUCASS 36 (TMS 01/1368, positive check). In addition, selection criteria recommended for further evaluation is based on total carotene content, dry matter content, yield parameters and resistance to biotic and abiotic stresses. Finally, 3 genotypes were selected from this investigation to be used as a platform for the introgression of other desirable traits through genetic modification.

\section{CONFLICT OF INTEREST}

The authors confirm that this article content has no conflict of interest.

\section{ACKNOWLEDGEMENTS}

Thanks to African Women in Agricultural Research and Development (AWARD) for their encouragement and financial support and also to numerous colleagues who have contributed so keenly towards the success of this work.

\section{REFERENCES}

[1] World Health Organization. Global prevalence of vitamin A deficiency (MDIS Working Paper No. 2. WHO/NUT/95.3), 1995.

[2] La Frano, M.; Woodhouse, L. R.; Burnett, J.D.; Burri, B.J. Biofortified cassava increases b-carotene and vitamin A concentrations in the TAG-rich plasma layer of American women. Br. J. Nutr., 2013, 2, 310-320.

[3] West, K.P., Jr Vitamin A deficiency disorders in children and women. Food Nutr. Bull., 2003, 24(4)(Suppl.), S78-S90. [http://dx.doi.org/10.1177/15648265030244S204] [PMID: 17016949]

[4] Njoku, D.N.; Vernon, G.; Egesi, C.N.; Asante, I.; Offei, S.K.; Okogbenin, E.; Kulakow, P.; Eke-okoro, O.N.; Ceballos, H. Breeding for Enhanced $\beta$-Carotene Content in Cassava: Constraints and Accomplishments. J. Crop Improv., 2011, 25(5), 560-571. [http://dx.doi.org/10.1080/15427528.2011.594978]

[5] Chávez, A.L.; Sánchez, T.; Jaramillo, G.; Bedoya, J.M.; Echeverry, J.; Bolaños, E.A.; Ceballos, H.; Iglesias, C.A. Variation of quality traits in cassava roots evaluated in landraces and improved clones. Euphytica, 2005, 143, 125-133. [http://dx.doi.org/10.1007/s10681-005-3057-2]

[6] Latham, M.C. Hidden hunger and the role of public-private partnership. Food Nutr. Bull., 2003, 24(4)(Suppl.), S67-S68. [http://dx.doi.org/10.1177/15648265030244S202] [PMID: 17016947] 
[7] Welch, R.M. Breeding strategies for biofortified staple plant foods to reduce micronutrient malnutrition globally. J. Nutr., 2002, 132(3), 495S-499S.

[PMID: 11880578]

[8] Ceballos, H. Spatial distribution of dry matter in yellow fleshed cassava roots and its influence on carotenoid retention upon boiling. Food Res. Int., 2012, 45(1), 52-59. [http://dx.doi.org/10.1016/j.foodres.2011.10.001]

[9] Njoku, D.N.; Egesi, C.N.; Gracen, V.E.; Offei, S.K.; Asante, I.K.; Danquah, E.Y. Identification of Pro-Vitamin A Cassava (Manihot esculenta Crantz) Varieties for Adaptation and Adoption through Participatory Research. J. Crop Improv., 2014, 28(3), $361-376$. [http://dx.doi.org/10.1080/15427528.2014.888694]

[10] Nyerhovwo, J.T. Cassava and the future of starch. Electron. J. Biotechnol., 2004, 7(1), 1-4.

[11] Nwokoro, S.O.; Orheruata, A.M.; Ordiah, P.I. Replacement of maize with cassava sievates in cockerel starter diets: effect on performance and carcass characteristics. Trop. Anim. Health Prod., 2002, 34(2), 163-167. [http://dx.doi.org/10.1023/A:1014222323984] [PMID: 11969113]

[12] Asare, A. P.; Teye, E.; Amoah, R. S.; Tetteh, J. P Determination of the dry matter content of cassava (Manihot esculenta, Crantz) tubers using specific gravity method. ARPN J. Agric. Biological Sci., 2011, 6(11), 23-28.

[13] Rodriguez-Amaya, D.D.; Kimura, M. "Harvest Plus Handbook for Carotenoid Analysis”. International Food Policy Research Institute; IFPRI: Washington, D.C, 2004, pp. 34-36.

[14] The Guardian. 2014. Available at: www.ngrguardiannews.com [2014, July 2].

[15] Combs, G.F. The Vitamins. Fundamental aspects in nutrition and health; Academic Press: London, UK, 1998.

[16] Ortiz, D.; Sánchez, T.; Morante, N.; Hernán, C.; Pachón, H.H.; Escobar, A.F. Sampling strategies for proper quantification of carotenoid content in cassava breeding. J. Plant. Breed. Crop. Sci., 2011, 3(1), 14-23.

[17] Baiyeri, K.P.; Edibo, G.O.; Obi, I.U.; Egesi, F.O.; Eke-Okoro, C.N.; Okogbenin, O.N.; Dixon, A.G. Growth, yield and disease responses of 12 cassava genotypes evaluated for two cropping seasons in a derived savannah zone of south-eastern nigeria. Agro-science J. Trop. Agric. Food Environ. Ext., 2008, 7(2), 162-169.

[18] Akinbo, O. Introgression of whitefly (Aleurotrachelus socialis) resistance gene from F1 inter-specific hybrids into commercial cassava. Euphytica, 2012, 183(1), 19-26.

[19] Raji, A. Screening landraces for additional sources of field resistance to cassava mosaic disease and green mite for integration into the cassava improvement program. J. Integr. Plant Biol., 2008, 50(3), 3111-318.

[20] Evans, L.T. Crop Evolution, Adaptation and Yield; Cambridge Univ. Press, 1993, p. 500.

[21] Maroya, N.G.; Kulakow, P.; Dixon, G.O.; Maziya-Dixon, B.B. Genotype and Environment Interaction of Mosaic Disease, Root Yields and Total Carotene Concentration of Yellow-Fleshed Cassava in Nigeria. Int. J. Agronomy, 2012, 2012(2012) Article ID 434675.

(C) Edoh et al.; Licensee Bentham Open

This is an open access article licensed under the terms of the Creative Commons Attribution-Non-Commercial 4.0 International Public License (CC BY-NC 4.0) (https://creativecommons.org/licenses/by-nc/4.0/legalcode), which permits unrestricted, non-commercial use, distribution and reproduction in any medium, provided the work is properly cited. 